\title{
Bacterial fibronectin-binding proteins and endothelial cell surface fibronectin mediate adherence of Staphylococcus aureus to resting human endothelial cells
}

\author{
Sharon J. Peacock, ${ }^{1,4}$ Timothy J. Foster, ${ }^{2}$ Brian J. Cameron ${ }^{1}$ \\ and Anthony R. Berendt ${ }^{3,4}$
}

\footnotetext{
1,3 Nuffield Department of Pathology and Bacteriology 1 , and Bone Infection Unit, Nuffield Orthopaedic Centre and Nuffield Department of Medicine ${ }^{3}$, The John Radcliffe Hospital, Headington, Oxford, UK

2 Microbiology Department, Moyne Institute of Preventive Medicine, Trinity College, Dublin 2, Ireland

4 Interdepartmental Academic Unit of Microbiology and Infectious Diseases, Oxford University, Oxford, UK
}

\author{
Author for correspondence: Sharon J. Peacock. Tel: +44 1865 220538. Fax: +44 1865220342. \\ e-mail: sharon.peacock@ndp.ox.ac.uk
}

\begin{abstract}
Adhesion of Staphylococcus aureus to human endothelial cells is implicated in the pathogenesis of invasive staphylococcal disease. The adhesion to endothelial cells of isogenic mutants defective in defined surface structures was studied. Three strains of $S$. aureus defective in fibronectin-binding proteins FnBPA and FnBPB showed reduced adhesion. This was fully restored by complementation of a FnBPA- FnBPB- mutant derived from strain 8325-4 with a multicopy plasmid encoding FnBPA or FnBPB. Adhesion of mutants defective in other surface structures was unaffected. Anti-fibronectin antibodies blocked adhesion of 8325-4 to endothelial cells, while adhesion of strains $\mathbf{8 3 2 5 - 4 , ~ P 1 ~ a n d ~ f i v e ~ c l i n i c a l ~ i s o l a t e s ~ w a s ~ i n h i b i t e d ~ b y ~ t h e ~ r e c o m b i n a n t ~}$ form of the binding domain of FnBPB (rFNBD) from Streptococcus dysgalactiae. Adherence of bacterial aggregates resulting from the presence of purified fibrinogen was also inhibited by rFNBD protein. Three strains of $S$. aureus defective in FnBPA and FnBPB were not internalized by endothelial cells. $S$. aureus FnBPs mediate adhesion to human endothelial cells and are required for subsequent internalization, interactions of potential relevance to pathogenesis and treatment.
\end{abstract}

Keywords: adherence, endothelium, fibronectin, Staphylococcus aureus

\section{INTRODUCTION}

Staphylococcus aureus is a major cause of communityacquired and nosocomial sepsis (Emori \& Gaynes, 1993; Steinberg et al., 1996; Communicable Disease Surveillance Centre, 1998). The clinical manifestations are widespread and include bacteraemia, endocarditis, pneumonia, osteomyelitis, septic arthritis and abscess formation. In the hospital setting, S. aureus is the leading cause of post-operative wound infection, and is prominent in medical-device-related sepsis including intravenous devices, prosthetic joints and peritoneal dialysis catheters (Waldvogel, 1995). The effective treatment of $S$. aureus sepsis is threatened by the continued rise in the incidence of methicillin-resistant $S$. aureus (MRSA) infection (Panlilio et al., 1992; Speller et al., 1997), combined with the recent emergence of MRSA strains also demonstrating intermediate sensitivity to

Abbreviation: FnBP, fibronectin-binding protein. vancomycin (Centers for Disease Control and Prevention, 1997; Hiramatsu et al., 1997a, b). There is thus a pressing need to increase our understanding of the pathogenesis of staphylococcal disease, as a basis for developing novel therapeutic and preventive approaches.

An important feature of $S$. aureus sepsis is the frequency with which it seeds from the bloodstream to other body sites. Bacterial metastasis from blood to tissues such as bones, joints and solid organs is clinically apparent in $1-53 \%$ of individuals with staphylococcal bacteraemia (reviewed by Ing et al., 1997) and must involve interactions between circulating bacteria and vascular endothelial cells. S. aureus adheres to human endothelial cells in vitro (Vercellotti et al., 1984; Ogawa et al., 1985) but, surprisingly, both the endothelial surface receptor(s) and the bacterial-cell-wall-associated adhesin(s) responsible remain undefined. Once adhesion has occurred $S$. aureus cells undergo a process akin to phagocytosis (Lowy et al., 1988; Yao et al., 1995). This 
internalization initiates changes in cytokine expression (Yao et al., 1995, 1996), and induces hyper-adhesiveness for monocytes and granulocytes (Beekhuizen et al., 1997). Following endothelial cell uptake, S. aureus has been demonstrated both within vacuoles and free in the cytoplasm (Menzies \& Kourteva, 1998). The subsequent fate of the endothelial cell varies between studies but appears to depend on the secretion of $\alpha$-toxin, which is cidal to endothelial cells (Vann \& Proctor, 1988). Lack of $\alpha$-toxin production by small colony variants may explain why these can persist in the intracellular niche without causing endothelial cell death (Balwit et al., 1994; von Eiff et al., 1997).

Attempts to define the endothelial receptor for $S$. aureus adherence have yielded a $50 \mathrm{kDa}$ membrane glycoprotein on human cells (Tompkins et al., 1990), and a $130 \mathrm{kDa}$ membrane glycoprotein on bovine cardiac endothelial cells (Johnson, 1993). Neither has been characterized further. Acidic fibroblast growth factor has been reported to reduce bacterial adherence (Blumberg et al., 1988), which is also modulated by extracellular matrix heparan sulfate (Alston et al., 1997), while human tumour necrosis factor has been shown to enhance adhesion to glutaraldehyde-fixed endothelial cells in the presence of plasma (Cheung et al., 1991a). In the latter model, fibrinogen has been reported to act as a bridging molecule in adherence (Cheung et al., 1991b) without definition of the cognate ligands for it on either cell type.

The bacterial determinants that promote adhesion of $S$. aureus to endothelium have not been elucidated. The majority of clinical isolates produce capsular polysaccharide serotype 5 or 8 (Karakawa \& Vann, 1982), which when purified has been shown to bind to endothelial cells and result in release of interleukin-6 and interleukin-8 (Soell et al., 1995). However, this is inhibited by the presence of pooled human serum from healthy blood donors (Soell et al., 1995). S. aureus also expresses a range of cell-wall-associated proteins that promote adherence to extracellular matrix proteins and/or soluble plasma components (Foster \& McDevitt, 1994). The fibrinogen-binding protein ClfA and collagen-binding protein have been shown to be important in the pathogenesis of experimental endocarditis (Moreillon et al., 1995; Hienz et al., 1996). The fibronectin- and fibrinogen-binding proteins of $S$. aureus promote bacterial attachment to plasma clots (Raja et al., 1990; Moreillon et al., 1995), and to plastic coated with these host proteins in vitro and ex vivo (Vaudaux et al., 1989, 1993, 1995; Greene et al., 1995). It is possible that these observations have direct relevance to the mechanisms by which $S$. aureus adheres to host cells, given that endothelial cells synthesize and incorporate fibronectin into the extracellular matrix, and secrete it into the culture medium when grown in vitro (Jaffe \& Mosher, 1978).

The aim of this study was to evaluate the role of a number of bacterial surface structures in adherence of $S$. aureus to endothelial cells in vitro. The approach taken was to compare the adherence of a range of defective mutants with that of the isogenic parent as a means of identifying candidate adhesins and cognate receptors for further study. Our results indicate that the interaction between the fibronectin-binding proteins (FnBPs) and endothelial-cell-associated fibronectin represents the dominant pathway for the adherence of $S$. aureus to human endothelial cells in vitro, and that FnBPs are required for subsequent bacterial internalization.

\section{METHODS}

Chemicals and reagents. All chemicals and reagents were obtained from Sigma-Aldrich, unless otherwise indicated. Culture media (Medium M199 and PBS) were from Gibco Life Technologies. Falcon tissue culture plasticware was obtained from Becton Dickinson.

Bacterial strains. The laboratory strains of $S$. aureus used, and their sources, are listed in Table 1. The clinical strains JR75, JR76, JR77, JR78 and JR80 were isolated in the Oxford microbiology department in 1995 from blood cultures of patients with native valve $S$. aureus endocarditis. Phillips and PH100 were gifts from Drs Magnus Höök and Jo Patti, Texas.

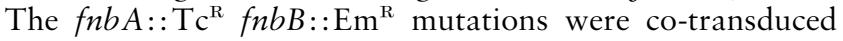
from DU5883 to strain P1 and JR80 by phage-85-mediated transduction (Asheshov, 1966). Transductants resistant to $2 \mu \mathrm{g}$ tetracycline $\mathrm{ml}^{-1}$ and $10 \mu \mathrm{g}$ erythromycin $\mathrm{ml}^{-1}$ were selected. The lack of adherence to purified human fibronectin at $10 \mu \mathrm{g} \mathrm{ml}^{-1}$ (Sigma) was confirmed by microtitre adherence assay using an established method (data not shown) (Hartford et al., 1997).

Bacterial storage, growth and harvest. Bacterial isolates were stored in trypticase soy broth with glycerol $(15 \%, \mathrm{v} / \mathrm{v})$ at $-80^{\circ} \mathrm{C}$. Isolates were inoculated from frozen stocks into $10 \mathrm{ml}$ Todd-Hewitt broth (Difco Laboratories) contained in $35 \mathrm{ml}$ glass universal containers and incubated for 15-18 h under constant rotation at $37^{\circ} \mathrm{C}$ in air. S. aureus DU5883(pFNBA4) and DU5883(pFNBB4) were cultured in Todd-Hewitt broth supplemented with $10 \mu \mathrm{g}$ chloramphenicol ml-1 to maintain plasmid selection. Purity of stock cultures was checked by simultaneous subculture onto blood agar with visual inspection of colony morphology after overnight incubation at $37^{\circ} \mathrm{C}$ in air. Bacteria were collected from broth culture by centrifugation at 3000 r.p.m. for $10 \mathrm{~min}$, washed four times with PBS, resuspended in Medium M199 with Earle's salt and $25 \mathrm{mM}$ HEPES (M199) and filtered through a sterile $5 \mu \mathrm{m}$ filter (Gelman Sciences) to remove bacterial aggregates. A subsequent Gram stain showed the cell suspension to comprise bacteria singly or in pairs. Final bacterial concentrations were adjusted to an $\mathrm{OD}_{650}$ of $0 \cdot 90-0 \cdot 94$, corresponding to a c.f.u. count of approximately $1 \times 10^{9}$ c.f.u. $\mathrm{ml}^{-1}$ on viability counts as performed by serial dilution, inoculation onto blood agar and colony count after overnight incubation at $37^{\circ} \mathrm{C}$ in air.

Endothelial cell culture. Endothelial cells were obtained from human newborn umbilical vein using an adaptation of a previously described method (Jaffe et al., 1973a). Both ends of the cord vein were cannulated using a Portex luerlock adaptor (Southern Syringe), after which the vessel was flushed with PBS. Cells were released by instilling M199 supplemented with $50 \mathrm{U}$ penicillin $\mathrm{ml}^{-1}$ (Gibco), $50 \mu \mathrm{g}$ streptomycin $\mathrm{ml}^{-1}$ (Gibco) and $0.5 \mathrm{mg}$ collagenase type IA $\mathrm{ml}^{-1}$ into the vessel lumen. After incubation for $20 \mathrm{~min}$ at $37^{\circ} \mathrm{C}$ the cell suspension was collected by centrifugation, resuspended in M199 supple- 
Table 1. Strains of $S$. aureus used in this study

\begin{tabular}{|c|c|c|c|}
\hline Strain & Relevant genotype & Properties & Reference \\
\hline $8325-4$ & & NCTC 8325 cured of prophages & Novick (1967) \\
\hline DU5883 & $f n b A:: \mathrm{Tc}^{\mathrm{R}} f n b B:: \mathrm{Em}^{\mathrm{R}}$ & $\begin{array}{l}\text { Mutant strain of 8325-4 defective in FnBPs A } \\
\text { and B }\end{array}$ & Greene et al. (1995) \\
\hline DU5883(pFNBA4) & $\begin{array}{l}f n b A:: \mathrm{Tc}^{\mathrm{R}} f n b B:: \mathrm{Em}^{\mathrm{R}} \\
\quad\left(\mathrm{pFNBA} 4: f n b A^{+} \mathrm{Cm}^{\mathrm{R}}\right)\end{array}$ & $\begin{array}{l}\text { Mutant strain of } 8325-4 \text { defective in FnBPs, } \\
\text { complemented with multicopy plasmid } \\
\text { expressing } f n b A^{+}\end{array}$ & Greene et al. (1995) \\
\hline DU5883(pFNBB4) & $\begin{array}{l}f n b A:: \mathrm{Tc}^{\mathrm{R}} f n b B:: \mathrm{Em}^{\mathrm{R}} \\
\left(\mathrm{pFNBB} 4: f n b B^{+} \mathrm{Cm}^{\mathrm{R}}\right)\end{array}$ & $\begin{array}{l}\text { Mutant strain of } 8325-4 \text { defective in FnBPs, } \\
\text { complemented with multicopy plasmid } \\
\text { expressing } f n b B^{+}\end{array}$ & Greene et al. (1995) \\
\hline DU5880 & clfA1:: $\operatorname{Tn} 917\left(\mathrm{Em}^{\mathrm{R}}\right)$ & $\begin{array}{l}\text { Mutant strain of } 8325-4 \text { defective in fibrinogen- } \\
\text { binding protein ClfA }\end{array}$ & McDevitt et al. (1994) \\
\hline DU5857 & $\Delta c o a:: \mathrm{Em}^{\mathrm{R}}$ & Mutant strain of $8325-4$ defective in coagulase & Phonimdaeng et al. (1990) \\
\hline DU5875 & $\Delta s p a:: \mathrm{Tc}^{\mathrm{R}}$ & Mutant strain of $8325-4$ defective in protein A & Patel et al. (1987) \\
\hline Phillips & & $\begin{array}{l}\text { Clinical osteomyelitis isolate expressing } \\
\text { collagen-binding protein }\end{array}$ & Patti et al. (1994a) \\
\hline PH100 & $c n a:: \mathrm{Gm}^{\mathrm{R}}$ & $\begin{array}{l}\text { Mutant strain of Phillips defective in collagen- } \\
\text { binding protein }\end{array}$ & Patti et al. (1994a) \\
\hline Newman & & High level of fibrinogen-binding protein ClfA & Duthie \& Lorenz (1952) \\
\hline DU5917 & cps1:: $\operatorname{Tn} 917\left(\mathrm{Em}^{\mathrm{R}}\right)$ & $\begin{array}{l}\text { Mutant strain of Newman defective in capsular } \\
\text { polysaccharide }\end{array}$ & Sau et al. (1997) \\
\hline P1 & & $\begin{array}{l}\text { Isolated from a rabbit inoculated with ATCC } \\
25923\end{array}$ & Sherertz et al. (1993) \\
\hline DU5947 & $f n b A:: \mathrm{Tc}^{\mathrm{R}} f n b B:: \mathrm{Em}^{\mathrm{R}}$ & Mutant strain of P1 defective in FnBPs A and B & This study \\
\hline DU5908 & clfA1:: $\operatorname{Tn} 917\left(\mathrm{Em}^{\mathrm{R}}\right)$ & $\begin{array}{l}\text { Mutant strain of P1 defective in fibrinogen- } \\
\text { binding protein ClfA }\end{array}$ & $\begin{array}{l}\text { T. J. Foster, personal } \\
\text { communication }\end{array}$ \\
\hline JR80 & & Isolate from a patient with endocarditis & This study \\
\hline DU5953 & $f n b A:: \mathrm{Tc}^{\mathrm{R}} f n b B:: \mathrm{Em}^{\mathrm{R}}$ & $\begin{array}{l}\text { Mutant strain of JR80 defective in FnBPs A } \\
\text { and B }\end{array}$ & This study \\
\hline
\end{tabular}

mented with fetal bovine serum (20\%, v/v; Gibco), $90 \mu \mathrm{g}$ heparin $\mathrm{ml}^{-1}, 5 \mathrm{ng}$ recombinant fibroblast growth factor $\mathrm{ml}^{-1}$, $50 \mathrm{U}$ penicillin $\mathrm{ml}^{-1}$ and $50 \mu \mathrm{g}$ streptomycin $\mathrm{ml}^{-1}$ and seeded into a $25 \mathrm{~cm}^{2}$ tissue culture flask. Cells were maintained at $37{ }^{\circ} \mathrm{C}$ in $5 \% \mathrm{CO}_{2}$ and passaged twice on reaching confluence using a 1:3 split, before subculture onto $13 \mathrm{~mm}$ Thermanox coverslips (Gibco) in 24-well tissue culture plates. All flasks and coverslips used in cell culture were pre-coated with gelatin $(0 \cdot 2 \%, \mathrm{v} / \mathrm{v})$ overnight at $37^{\circ} \mathrm{C}$. The identity of the cells was confirmed as endothelial by their cobblestone appearance at confluency, and positive immunofluorescent staining for von Willebrand factor (Jaffe et al., 1973b).

Endothelial cell adhesion assay. Sterile 24-well flat-bottomed tissue culture plates were blocked with BSA $(1 \%, \mathrm{w} / \mathrm{v})$ for $1 \mathrm{~h}$ and rinsed twice with PBS. A bacterial inoculum of $10^{8}$ c.f.u. suspended in $500 \mu \mathrm{l} \mathrm{M199}$ was added to each well. This inoculum was selected on the basis of dose response curves (data not shown). Confluent endothelial cells coating $13 \mathrm{~mm}$ Thermanox coverslips were added after dip-washing three times in M199 to remove traces of culture media. The 24-well plates were incubated at $37^{\circ} \mathrm{C}$ in $\mathrm{CO}_{2}$ for $1 \mathrm{~h}$. This incubation period was selected on the basis of time-course studies (data not shown). The coverslips were then dip-washed three times in M199 and once in PBS to remove non-associated bacteria. The endothelial cells were fixed with Cytofix (Cellpath), airdried, and stained with crystal violet $(0 \cdot 5 \%, \mathrm{w} / \mathrm{v})$ for $5 \mathrm{~min}$. Following dip-rinsing in water, the coverslips were air-dried and mounted on glass slides. The number of endothelial-cell- associated bacteria was quantified using a visual method. The bacterial count included both adherent and internalized bacteria, but for simplicity bacteria are referred to as adherent in the remainder of the text. Bacteria prepared for the adhesion assay as above were shown not to divide over the course of an hour in binding medium (data not shown), making the number of visualized bacteria an accurate representation of those that had adhered. Each coverslip was scanned under low power to ensure confluence and integrity of the monolayer. Using a calibrated graticule under oil immersion and a $\times 100$ magnification lens, the number of bacteria associated with $1 \mathrm{~mm}^{2}$ of confluent endothelial cells was enumerated by a standardized counting procedure. Without prior visual inspection at high power, five high-power fields were selected for counting, as follows: (1) the centre of the coverslip; (2) two points between the centre and left edge; and (3) two points between the centre and right edge.

Endothelial cell internalization assay. Internalization of $S$. aureus by endothelial cells was evaluated by incubating the monolayer with lysostaphin at the end of the adherence assay. This has been shown to remove $S$. aureus that is adherent to the monolayer but does not affect the viability of internalized bacteria (Vann \& Proctor, 1987). The endothelial cell adhesion assay was performed using the method described above, at the end of which coverslips were rinsed three times in M199 and placed into 24-well plates containing lysostaphin at $10 \mu \mathrm{g} \mathrm{ml}^{-1}$ in M199 or M199 alone. These were incubated for $20 \mathrm{~min}$ at $37^{\circ} \mathrm{C}$ in $\mathrm{CO}_{2}$ then fixed and stained as before. Crystal violet 
was shown to penetrate the endothelial cell and stain internalized bacteria. The numbers of internalized bacteria per $\mathrm{mm}^{2}$ in the lysostaphin-treated monolayers were compared with the total bacterial count (adherent plus intracellular) for the controls. Internalization was also examined in a second assay in which $10^{8}$ c.f.u. were centrifuged onto the surface of the endothelium during a $5 \mathrm{~min}$ spin at 1000 r.p.m. The adherence assay was then allowed to continue over $1 \mathrm{~h}$ at $37^{\circ} \mathrm{C}$ in $\mathrm{CO}_{2}$, followed by lysostaphin treatment as described above. The $60 \mathrm{~min}$ time point used to examine internalization in this assay was selected on the basis of time-course studies (data not shown). Coverslips were rinsed, fixed and stained, and the numbers of bacteria per $\mathrm{mm}^{2}$ were counted using the standardized counting procedure.

Competitive endothelial binding inhibition assay with the recombinant form of the ligand-binding domain of FnBP. Endothelial cell adhesion assays were performed using the method described above, with the exception that the recombinant form of the ligand-binding domain of FnBPB of Streptococcus dysgalactiae (Joh et al., 1994) (rFNBD-B; a gift from Dr Magnus Höök, Texas, referred to below as rFNBD protein) was added to the wells immediately prior to bacterial inoculation at a final concentration of $1 \mu \mathrm{g} \mathrm{ml}^{-1}, 10 \mu \mathrm{g} \mathrm{ml}^{-1}$ or $50 \mu \mathrm{g} \mathrm{ml} \mathrm{m}^{-1}$. To control for the possibility that recombinant protein non-specifically interfered with bacterial adherence, parallel assays were performed in the presence of a recombinant truncated ClfA protein (Clf41, residues 221-559) (O'Connell et al., 1998) at a final concentration of $25 \mu \mathrm{g} \mathrm{ml}^{-1}$. A second control was bacteria in the absence of recombinant protein. The total volume was maintained at $500 \mu \mathrm{l}$ for all wells.

Effect of anti-human fibronectin antibodies on adhesion to endothelial cells. The effect on adherence of anti-human fibronectin antibodies was evaluated using 8325-4 defective in protein A (DU5875) so as to control for the confounding interaction between protein $\mathrm{A}$ and the Fc region of IgG. The following antibodies were used at a concentration of $10 \mu \mathrm{g}$ $\mathrm{ml}^{-1}$ : rabbit polyclonal antibody to purified human fibronectin (F3648; Sigma); sheep polyclonal antibody to purified human fibronectin (Serotec UK; Oxford); $\mathrm{mAb}$ recognizing an epitope located within the 5th type III repeat of human plasma fibronectin (mouse IgG1 clone IST-4; F 0916, Sigma); and $\mathrm{mAb}$ recognizing the $\mathrm{N}$-terminus of fibronectin (mouse IgG3 clone 10B7; Biogenesis). The following control antibodies were used at a concentration of $10 \mu \mathrm{g} \mathrm{ml}^{-1}$ : normal sheep IgG (I 5131, Sigma); normal rabbit IgG (I 5006, Sigma); mouse IgG1, Kappa (MOPC-31C; M 9035, Sigma); and mouse IgG3, Kappa (FLOPC 21; M 3645, Sigma). All antibodies were added to the wells immediately prior to bacterial inoculation.

Bacterial adhesion to solid-phase purified fibronectin. Purified human fibronectin at $10 \mu \mathrm{g} \mathrm{ml}^{-1}$ (Sigma) in TBS was spotted onto tissue culture grade plastic Petri dishes and incubated at $37^{\circ} \mathrm{C}$ in air for $1 \mathrm{~h}$, then flooded with $1 \%$ BSA in TBS and maintained overnight at $4^{\circ} \mathrm{C}$. Dishes were rinsed twice in M199 immediately prior to use. After bacterial preparation as described above, strains were suspended in M199 with $1 \%$ BSA to a final concentration of $5 \times 10^{7}$ c.f.u. $\mathrm{ml}^{-1}$ and $1.5 \mathrm{ml}$ was added to each dish. Following incubation at $37^{\circ} \mathrm{C}$ in air for $1 \mathrm{~h}$, the dishes were rinsed four times with M199, fixed with glutaraldehyde (2\%,v/v) in M199 for $2 \mathrm{~h}$ and stained with $0.5 \%$ crystal violet for $5 \mathrm{~min}$. Adhesion was quantified using a visual method. The purified fibronectin spots were examined using a calibrated graticule under oil immersion with $a \times 100$ magnification lens. The number of bacteria adherent to an area of $1 \mathrm{~mm}^{2}$ purified protein were enumerated by a standardized counting procedure. Without prior visual inspection at high power, five high-power fields were selected for counting, as follows: (1) the centre of the protein spot; (2) two points between the centre and left edge; and (3) two points between the centre and right edge.

Endothelial cell adhesion assays after pre-coating with, or in the presence of, fibrinogen and fibronectin. Adherence assays were performed using one of two modifications. (1) Confluent endothelial cells coating Thermanox coverslips were precoated for $30 \mathrm{~min}$ at $37^{\circ} \mathrm{C}$ in air with either purified human fibronectin at $300 \mu \mathrm{g} \mathrm{ml} \mathrm{m}^{-1}$ (Sigma), or purified human fibrinogen at $1 \mathrm{mg} \mathrm{ml}^{-1}$ (Sigma). The coverslips were then diprinsed in M199 four times prior to use in the adherence assay. (2) Adherence assays were performed in the presence of either purified human fibronectin at $300 \mu \mathrm{g} \mathrm{ml} \mathrm{m}^{-1}$ or purified fibrinogen at $1 \mathrm{mg} \mathrm{ml}^{-1}$, with or without rFNBD protein. Contamination of commercially available human fibrinogen by fibronectin is a potential confounder in endothelial cell adherence assays. The human fibrinogen used in this study was evaluated and purified prior to use, as follows. The presence of contaminating fibronectin was confirmed by Western blotting following fractionation by SDS-PAGE of a $15 \mu \mathrm{l}$ aliquot of fibrinogen solution, $2 \mathrm{mg} \mathrm{ml}^{-1}$, dissolved in M199, as previously described by McDevitt et al. (1992) (data not shown). Fibronectin was removed by passing the fibrinogen solution through a gelatin-Sepharose column (Pharmacia Biotech) using the procedure described by the manufacturer. The absence of contaminating fibronectin in the eluate was confirmed by Western blot. Western blotting did not demonstrate the presence of contaminating immunoglobulin.

Statistical analysis. Results for the numbers of bacteria adherent to or internalized by endothelium, or adherent to purified fibronectin, were expressed as the mean count per $1 \mathrm{~mm}^{2}$ surface area. All points were performed in triplicate and each experiment was performed three times. Statistical analysis was carried out using the Statview 4.5 statistical software package (Abacus). Comparison of the mean count between bacterial strains was performed using an unpaired $t$ test with correction for multiple comparisons.

\section{RESULTS}

\section{Isogenic mutants deficient in FnBP demonstrate reduced binding to endothelial cells}

Adhesion to live endothelium was compared for the isogenic mutants and parental strains shown in Table 1. Evaluation of 8325-4 and related mutants demonstrated a significant reduction in the number of adherent bacteria for the 8325-4 FnBP-deficient mutant (Fig. 1). This contrasted with 8325-4 mutants defective in coagulase, protein A or fibrinogen-binding protein ClfA, for which adhesion was unaffected (Fig. 1). There was no difference between strain Newman and its isogenic mutant defective in capsular polysaccharide $196 \%$ of that for the parent, $P>0.05)$, or strain Phillips and its isogenic mutant defective in collagen-binding protein $(104 \%$ of that for the parent, $P>0.05$ ) (data not shown). The reduction in adherence of the 8325-4 FnBPdeficient mutant was reproducible using FnBP-deficient mutants of strains P1 and JR80. The bacterial count for $S$. aureus P1 and JR80 defective in FnBPA and FnBPB was $9 \cdot 2 \%$ and $14.7 \%$, respectively, compared with that 


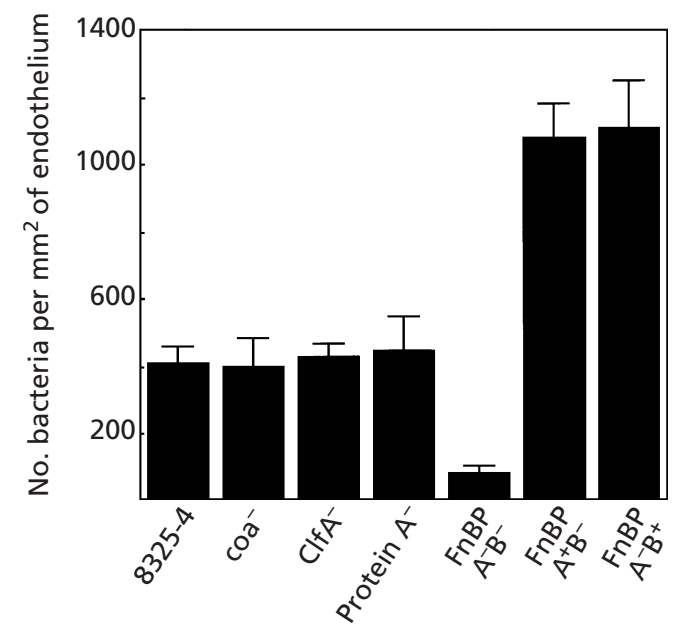

Fig. 1. Adherence of $S$. aureus $8325-4$ mutants to human endothelial cells in vitro. The numbers of bacteria per $\mathrm{mm}^{2}$ of endothelium were quantified visually, and are shown above for the mean of triplicate experiments \pm SEM. The isogenic mutants of 8325-4 were defective in coagulase, the fibrinogen-binding protein ClfA, protein A or FnBPA and FnBPB. The bacterial count for the 8325-4 FnBP-deficient mutant was significantly reduced compared with that for wild-type 8325-4 $(P=0.0008)$, but was unaffected by the remaining mutations $(P>0.05)$. The effect of complementation of the 8325-4 FnBP-deficient mutant with a multicopy plasmid encoding either $f n b A^{+}$or $f n b B^{+}$on adhesion to endothelial cells was assessed. $\mathrm{FnBPA}^{+} \mathrm{B}^{-}$is the double FnBP mutant complemented with pFNBA4 encoding fnbA, and $\mathrm{FnBPA}^{-} \mathrm{B}^{+}$is the double FnBP mutant complemented with pFNBB4 encoding $f n b B$. Both complemented strains demonstrated significantly greater levels of adhesion than that of the FnBP-deficient mutant $(P<0.0001$ and $P=0.0003$, respectively), and the wild-type parental strain $(P=0.0012$ and 0.0024 , respectively).

for the parent strains $(P<0.0001$ in both cases) (data not shown).

\section{Complementation of the 8325-4 FnBP-deficient mutant with a multicopy plasmid restores endothelial binding}

Further evidence for the involvement of $S$. aureus FnBP in bacterial adherence to endothelial cells was provided by adhesion assays using the 8325-4 FnBP-deficient mutant complemented with a multicopy plasmid encoding either $f n b A^{+}$(pFNBA4) or $f n b B^{+}$(pFNBB4). Adherence was fully restored, both complemented strains demonstrating significantly greater levels of adhesion than that of both the FnBP-deficient mutant and the wild-type parental strain (Fig. 1).

\section{The recombinant form of the ligand-binding domain of FnBP-B from Streptococcus dysgalactiae inhibits endothelial binding of $S$. aureus}

The ligand-binding activity of the $S$. aureus FnBP is located in region $\mathrm{D}$, which is composed of three consecutive repeats of 37 or 38 residues (designated D1, D2 and D3), plus one incomplete repeat (D4) (Raja et

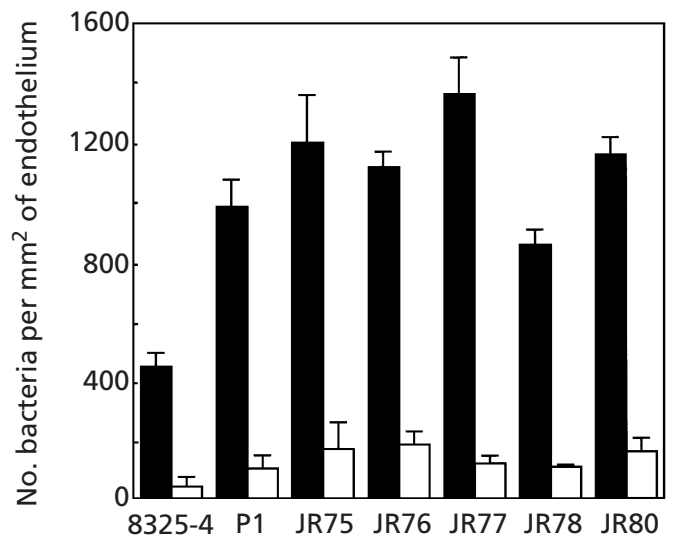

Fig. 2. Effect of the recombinant form of the ligand-binding domain of FnBP-B from Streptococcus dysgalactiae on adhesion to endothelial cells in vitro. Adherence assays were performed for the laboratory strains S. aureus $8325-4$ and P1, and five clinical isolates (JR75-JR78 and JR80 isolated from patients with community-acquired native valve endocarditis), in the absence ( $\square$ ) or presence $(\square)$ of the recombinant form of the ligandbinding domain of FnBP encoded by $f n b B$ of Streptococcus dysgalactiae $\left(10 \mu \mathrm{g} \mathrm{ml}^{-1}\right)$. The numbers of bacteria per $\mathrm{mm}^{2}$ of endothelium were quantified visually, and are shown above for the mean of triplicate experiments \pm SEM. There was a significant reduction in the presence of rFNBD protein for all isolates $(P<0.0001)$.

al., 1990; Signas et al., 1989). D1-D3 comprises a highaffinity binding domain, while synthetic peptides representing each motif demonstrate low-affinity binding and the ability to inhibit fibronectin binding to $S$. aureus in a competitive manner (Huff et al., 1994). The involvement of this domain in the interaction between $S$. aureus FnBP and human endothelial cells was evaluated by competitive adherence inhibition assays using the recombinant form of the binding domain of FnBP-B from Streptococcus dysgalactiae. This protein has been shown to inhibit the binding of ${ }^{125}$ I-labelled intact fibronectin or the N-terminal fibronectin domain to $S$. aureus (Joh et al., 1994). We speculated that if the $S$. aureus FnBPs were interacting with endothelial surface fibronectin, adhesion would be inhibited by rFNBD protein.

The effect of $10 \mu \mathrm{g} r F N B D$ protein $\mathrm{ml}^{-1}$ on adherence of $S$. aureus $8325-4, \mathrm{P} 1$ and five recent clinical isolates is shown in Fig. 2. There was a significant reduction in count in the presence of $\mathrm{rFNBD}$ protein for all isolates, while the recombinant truncated ClfA protein (Clf41, residues 221-559) had no effect on adherence (range $89 \cdot 6-95 \cdot 5 \%$ of the control, $P>0 \cdot 05$ ) (data not shown). These results imply that the binding domain (D repeat region) of $S$. aureus FnBP participates in the interaction between $S$. aureus and the endothelial monolayer. Although markedly reduced, bacterial adhesion to the monolayer was not abolished at any of the concentrations of rFNBD protein used (data not shown). This concurs with the observation that FnBP-defective mutants can adhere to the monolayer, albeit at a reduced level compared to the parent strain. 


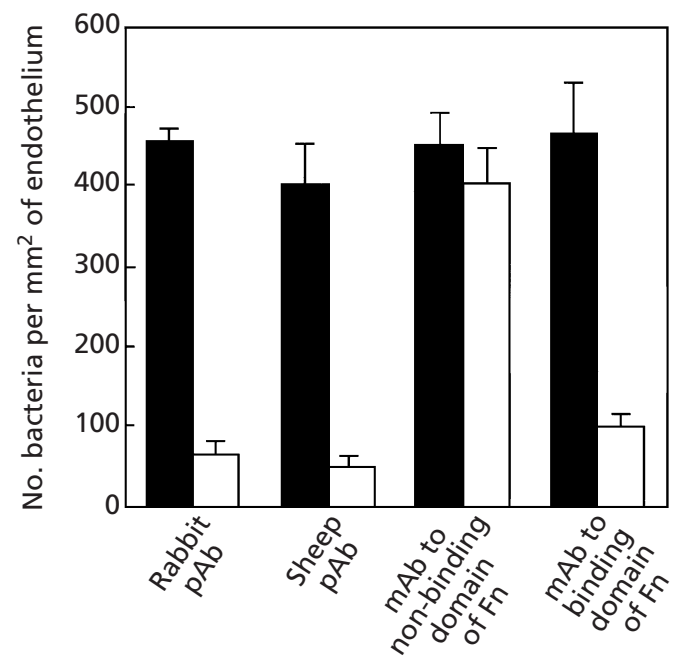

Fig. 3. Effect of anti-human fibronectin antibodies on the adherence of 8325-4 to human endothelial cells in vitro. Endothelial cell adhesion assays were performed for the protein-A-deficient 8325-4 mutant in the presence of a panel of anti-human fibronectin antibodies, as follows: rabbit polyclonal antibody ( $\mathrm{pAb}$ ); sheep polyclonal antibody; a mAb recognizing an area of fibronectin not thought to be involved in binding (an epitope located with the 5th type III module); and a mAb to the $\mathrm{N}$-terminus (binding region) of fibronectin. Adherence was compared with that occurring in the presence of control antibodies matched for source and type/isotype. The numbers of bacteria per $\mathrm{mm}^{2}$ of endothelium were quantified visually, and are shown above for the mean of triplicate experiments \pm SEM. $\square$, Control antibody; $\square$, test antibody. The bacterial count was reduced by the presence of rabbit or sheep polyclonal anti-human fibronectin antibodies $(P=0.0004$ in both cases), or a mAb to the $\mathrm{N}$-terminus of human fibronectin $(P=0.0008)$. A mAb recognizing the 5th type III repeat of human fibronectin had no significant effect.

\section{Inhibition of endothelial binding with anti- fibronectin antibodies}

The above findings suggest that fibronectin is the host cell surface receptor for adherence of $S$. aureus to endothelial cells in vitro. This was evaluated indirectly by examining the effect of a panel of anti-human fibronectin antibodies on adherence of the protein-Adefective mutant of 8325-4 (Fig. 3). A significant reduction in adhesion was seen in the presence of rabbit or sheep polyclonal anti-human fibronectin antibodies, or a $\mathrm{mAb}$ to the $\mathrm{N}$-terminus of human fibronectin. The number of adherent bacteria was not affected by a mAb recognizing the 5th type III repeat of human fibronectin.

\section{Adhesion of $S$. aureus to purified fibronectin correlates with endothelial binding}

Adherence to endothelial cells was compared with adherence to solid-phase purified human fibronectin for 8325-4 and related fibronectin mutants P1, JR80 and Newman. Adhesion to endothelial cells correlated with adhesion to purified fibronectin (data not shown). As

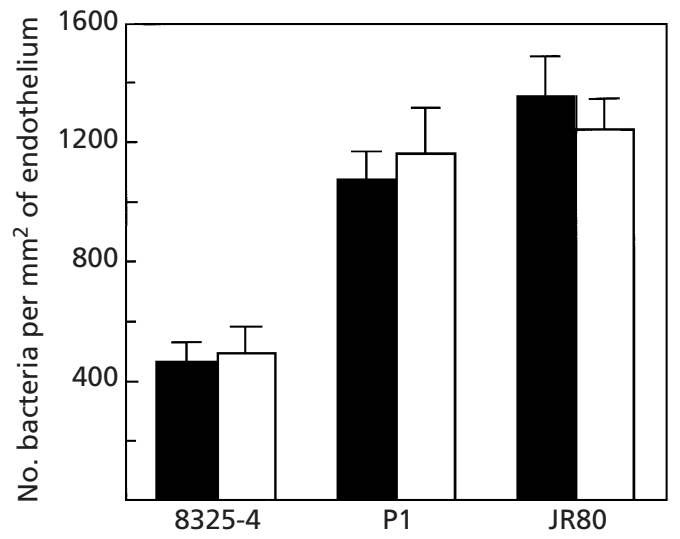

Fig. 4. Adherence of $S$. aureus to endothelial cells in vitro precoated with fibronectin. Endothelial monolayers were preincubated with purified human fibronectin at $300 \mu \mathrm{g} \mathrm{ml} \mathrm{m}^{-1}$ for $30 \mathrm{~min}$ followed by rinsing prior to use in the bacterial adherence assay. The numbers of adherent bacteria per $\mathrm{mm}^{2}$ of endothelium were quantified visually, and are shown above for the mean of triplicate experiments \pm SEM. $\square$, Control; $\square$, precoated endothelium.

predicted, the 8325-4 FnBP-deficient mutant showed no binding to purified fibronectin. The same mutant complemented with a multicopy plasmid expressing either $f n b A^{+}$(pFNBA4) or $f n b B^{+}$(pFNBB4) showed enhanced binding to fibronectin compared with the isogenic parent. This has been reported previously (Greene et al., 1995), and may be due to the expression of a higher number of FnBPs. S. aureus P1 adhered strongly to endothelial cells and fibronectin, while Newman adhered poorly to both substrates. The weak adherence of Newman to solid-phase fibronectin in this study has been observed by others (Vaudaux et al., 1995), and occurs despite the presence of two apparently functional $f n b$ genes that express FnBP protein detectable by ligand-affinity blotting (Greene, 1995). The association between the ability to adhere to solid-phase purified human fibronectin and endothelial cells provides further indirect evidence for fibronectin as the endothelial cell receptor for $S$. aureus.

\section{Effect of plasma proteins on adherence of $S$. aureus to endothelial cells}

Previous studies have shown that plasma proteins are involved in bacterial adherence to endothelium. We evaluated the role of such proteins by pre-coating endothelial monolayers with purified human fibronectin or fibrinogen, or by adding these host proteins into the assay.

Pre-coating the monolayer with fibronectin followed by rinsing prior to use in the adherence assay had no effect (Fig. 4). This contrasted with the effect of actually adding fibronectin to the assay, which led to agglutination of bacteria as described previously (Proctor et al., 1984) and adherence of aggregates to the monolayer (data not shown). 


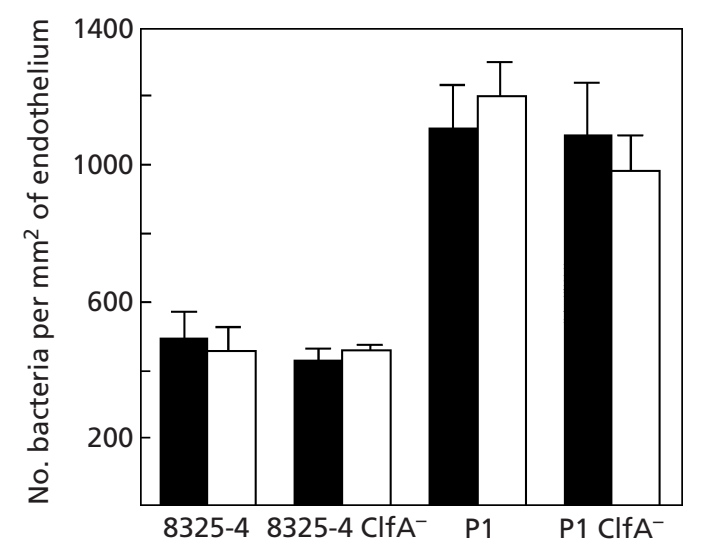

Fig. 5. Adherence of $S$. aureus to endothelial cells in vitro precoated with fibrinogen. Endothelial monolayers were preincubated with purified human fibrinogen at $1 \mathrm{mg} \mathrm{ml}^{-1}$ for $30 \mathrm{~min}$ followed by rinsing prior to use in the bacterial adherence assay. The numbers of adherent bacteria per $\mathrm{mm}^{2}$ of endothelium were quantified visually, and are shown above for the mean of triplicate experiments \pm SEM. $\square$, Control; $\square$, precoated endothelium. 8325-4 $\mathrm{ClfA}^{-}$and P1 $\mathrm{ClfA}^{-}$are isogenic mutants defective in the fibrinogen-binding protein ClfA.

Pre-coating the endothelial monolayer with fibrinogen also failed to influence adherence of $8325-4$ or P1 (Fig. $5)$. The adherence assay was repeated for mutants of 8325-4 and P1 defective in ClfA. There was no significant difference in adherence to fibrinogen-pre-coated endothelium between these two pairs (Fig. 5).

The relative importance of FnBP and ClfA in the adherence of $S$. aureus to endothelial cells in vitro in the presence of fibrinogen was then assessed by assays in which fibrinogen $\left.(1 \mathrm{mg} \mathrm{ml})^{-1}\right)$ was added, with or without $\mathrm{rFNBD}$ protein $\left(10 \mu \mathrm{g} \mathrm{ml}^{-1}\right)$. This was performed for 8325-4, P1 and the five clinical isolates (JR75-78 and JR80), which all behaved similarly. Fibrinogen alone resulted in the formation of a latticework of bacterial aggregates adherent to the monolayer. The entire inoculum appeared to become consumed into the aggregates, with virtually no bacteria adherent to the monolayer in singles, pairs or small clusters. In the presence of rFNBD protein and fibrinogen together, large bacterial aggregates formed but these were not adherent to the monolayer and were readily rinsed off at the end of the assay. Thus, $S$. aureus FnBPs appear to predominate in importance over the fibrinogen-binding protein ClfA during bacterial adherence to endothelial cells in the presence of fibrinogen.

\section{Endothelial cells do not internalize $S$. aureus mutants deficient in FnBP}

Using the adherence assay in which $10^{8}$ c.f.u. were incubated with the monolayer for $1 \mathrm{~h}$ with no prior centrifugation of bacteria onto the endothelium, the number of bacteria internalized by endothelial cells was $9 \%, 25 \%$ and $21 \%$ of the total (intracellular + adherent) for wild-type 8325-4, P1 and JR80, respectively (data not shown). This contrasted with the three isogenic FnBP-deficient mutants, for which no intracellular bacteria were visualized either in the standard $1 \mathrm{~mm}^{2}$ surface area of endothelium examined, or during detailed scanning of the monolayer in multiple fields. It is possible that the apparent lack of internalization of the FnBP-defective mutants resulted from the low number of bacteria adherent to the monolayer rather than interruption of a specific uptake pathway. This was examined by centrifuging $10^{8}$ c.f.u. onto the monolayer at the start of the adherence assay. The numbers of internalized bacteria per $\mathrm{mm}^{2}$ of endothelium after $60 \mathrm{~min}$ incubation at $37^{\circ} \mathrm{C}$ were 397 , 826 and 790, respectively, for $8325-4, \mathrm{P} 1$ and JR 80 . This compared with $<1$ bacterium per $\mathrm{mm}^{2}$ for FnBPdefective mutants of $8325-4$, P1 and JR80. The lack of intracellular bacteria for all three mutants indicates that FnBPs are critical for internalization of $S$. aureus by endothelial cells in vitro.

\section{DISCUSSION}

We have shown for the first time that the $S$. aureus FnBPs play an important role in adhesion to live human endothelial cells. Isogenic mutants defective in expression of FnBPs all showed marked reductions in adhesion to endothelial cells. This was true in two laboratory strains and a recent clinical isolate. Restoration, through plasmid complementation, of the fibronectin-binding ability of a FnBP-defective isogenic mutant also restored endothelial binding. Adhesion was inhibited by anti-fibronectin polyclonal and monoclonal antibodies, and by a recombinant fibronectin-binding domain from the FnBP of Streptococcus dysgalactiae. In addition to providing evidence that staphylococcal FnBPs interact with endothelial fibronectin, our data also indicate that this is through the known interaction of the D region of FnBP with the $\mathrm{N}$-terminal five type I domains of fibronectin (Sottile et al., 1991). Bacterial uptake by the endothelial monolayer was also dependent on the presence of FnBPs.

Our findings are important because they cast light on a key interaction in the pathogenesis of metastatic $S$. aureus infection, the adherence of bacteria to endothelial cells. Since this organism is able to infect apparently normal bone and joint tissues, a direct interaction with endothelial cells is likely as a first step in the invasion of these deeper tissues. Fibronectin is well placed to act as a receptor in this regard. It is a normal component of the extracellular matrix on the luminal surface of an endothelial monolayer and our findings are consistent with a previous report of the ultrastructural localization of fibronectin between bovine endothelial cells and adherent S. aureus (Vann et al., 1989). The observation that $S$. aureus 8325-4 has two FnBPs, FnBPA and FnBPB, encoded by the closely linked genes $f n b A$ and $f n b B$ (Signas et al., 1989; Jonsson et al., 1991) underscores the importance of interactions with fibronectin in the biology of the organism. Given that the defect in endothelial cell adhesion seen with the FnBP-deficient mutant was restored by the presence of a multicopy plasmid encoding one of $f n b A$ or $f n b B$, either FnBPA or 
FnBPB alone can mediate adherence of 8325-4. Understanding the relative importance of each protein in the interaction of staphylococci with endothelial cells will require further study.

Adhesion of $S$. aureus to live endothelial cells is rapidly followed by internalization, a process which requires the presence of bacterial FnBPs. Fibronectin, through its known interactions with integrin receptors present on endothelium (Albelda et al., 1989), is an ideal candidate molecule to orchestrate these events. Many other invasive pathogens use integrins as cellular receptors (for review see Berendt \& McCormick, 1997) and Streptococcus pyogenes has already been shown to invade a number of epithelial cell lines through the interaction between fibronectin and epithelial-cell-surface integrins (Ozeri et al., 1998). Our observations thus prompt the speculation that $S$. aureus invades endothelial cells through similar mechanisms.

Under physiological conditions, the interaction of $S$. aureus with endothelial cells takes place at greatly lower bacterial density, in whole blood and under conditions of flow. The relevant activation status of the endothelial cells in vivo is unknown and their phenotype will vary according to site. We previously showed that there are important differences between microvascular and large vessel endothelium in the expression and function of host receptors for the adhesion of malaria-infected erythrocytes (McCormick et al., 1997). Furthermore, for adhesion of both leukocytes and malaria-infected erythrocytes, endothelial receptors show differential adhesion under shear flow conditions, with 'rolling' and 'static' receptors. It therefore remains possible that under conditions of flow and cytokine activation, additional adhesion pathways operate independently of, or alongside, the fibronectin pathway. Elucidating this under the full range of conditions that might prevail in vivo requires further detailed studies.

Plasma proteins are also an important component of these interactions. We were surprised to find no convincing role in adhesion for fibrinogen, which has been previously reported to act as a bridging molecule (Cheung et al., 1991b). There are a number of differences between the previous study and our own that may explain this, including the bacterial strains used and the method of quantifying bacterial adherence. An additional difference is that the earlier group used an assay where the endothelial cells were fixed with glutaraldehyde. This may have modified the affinity or accessibility of the binding sites on the fibronectin molecules, rendering them unable to interact with the FnBPs on the bacteria. In support of this, we find that glutaraldehyde fixation of purified fibronectin that has been immobilized on plastic reduces the adherence of $S$. aureus $8325-4$ and the clinical isolate JR 80 to $5 \%$ and $8 \%$, respectively, of that for the non-treated control. We cannot exclude the possibilities that under different conditions of growth or activation, the fibronectin pathway plays a lesser role or that if it is inoperative, secondary adhesion mechanisms become important.
Indeed, in our system, low levels of residual bacterial binding (approx. 10-20\% of control) are seen when the fibronectin-binding pathway is non-functional due to mutation, $\mathrm{rFNBD}$ protein or anti-fibronectin antibodies. The receptor for this secondary pathway remains unidentified.

Finally, it is important to note that FnBPs are not unique to $S$. aureus, being widely distributed among the streptococci (reviewed by Patti et al., 1994b). Whether other organisms capable of causing complicated bacteraemias also adhere to endothelial cells by this route remains a matter for speculation and further study.

\section{ACKNOWLEDGEMENTS}

This work was supported by Wellcome Trust Microbiology Training Fellowship grant 044331, Wellcome Trust grant 52320, and BioResearch Ireland. A. R. B. was a Lister Institute Research Fellow. We are grateful for the assistance of C. McCormick during endothelial cell culture and purified protein adhesion assays. We are grateful to Magnus Höök for providing the bacterial strains Phillips and PH100, and rFNBD protein, and to the midwives of the John Radcliffe Hospital for providing umbilical cords. We thank Professor Richard Moxon for his support.

\section{REFERENCES}

Albelda, S. M., Daise, M., Levine, E. M. \& Buck, C. A. (1989). Identification and characterization of cell-substratum adhesion receptors on cultured human endothelial cells. J Clin Invest 83, 1992-2002.

Alston, W. K., Elliot, D. A., Epstein, M. E., Hatcher, V. B., Tang, M. \& Lowy, F. D. (1997). Extracellular matrix heparan sulfate modulates endothelial cell susceptibility to Staphylococcus aureus. J Cell Physiol 173, 102-109.

Asheshov, E. H. (1966). Loss of antibiotic resistance in Staphylococcus aureus resulting from growth at high temperatures. J Gen Microbiol 42, 403-410.

Balwit, J. M., van Langevelde, P., Vann, J. M. \& Proctor, R. A. (1994). Gentamicin-resistant menadione and hemin auxotrophic Staphylococcus aureus persist within cultured endothelial cells. J Infect Dis 170, 1033-1037.

Beekhuizen, H., van de Gevel, J. S., Olsson, B., van Benten, I. J. \& van Furth, R. (1997). Infection of human vascular endothelial cells with Staphylococcus aureus induces hyperadhesiveness for human monocytes and granulocytes. J Immunol 158, 774-782.

Berendt, A. R. \& McCormick, C. J. (1997). Use of host adhesion molecules by infectious agents. In Adhesion Molecules in Health and Disease, 1st edn, pp. 347-379. Edited by L. C. Paul \& T. B. Issekutz. New York: Marcel Dekker.

Blumberg, E. A., Hatcher, V. B. \& Lowy, F. D. (1988). Acidic fibroblast growth factor modulates Staphylococcus aureus adherence to human endothelial cells. Infect Immun 56, 1470-1474.

Centers for Disease Control and Prevention (1997). Update: Staphylococcus aureus with reduced susceptibility to vancomycin - United States, 1997. JAMA (J Am Med Assoc) 278, 1145-1146.

Cheung, A. L., Koomey, J. M., Lee, S., Jaffe, E. A. \& Fischetti, V. A. (1991a). Recombinant human tumour necrosis factor alpha promotes adherence of Staphylococcus aureus to cultured human endothelial cells. Infect Immun 59, 3827-3831. 
Cheung, A. L., Krishnan, M., Jaffe, E. A. \& Fischetti, V. A. (1991b). Fibrinogen acts as a bridging molecule in the adherence of Staphylococcus aureus to cultured human endothelial cells. J Clin Invest 87, 2236-2245.

Communicable Disease Surveillance Centre (1998). Bacteraemia and bacterial meningitis, England and Wales. Commun Dis Rep CDR Wkly 9, 254.

Duthie, E. S. \& Lorenz, L. L. (1952). Staphylococcal coagulase: mode of action and antigenicity. J Gen Microbiol 6, 95-107.

von Eiff, C., Heilmann, C., Proctor, R. A., Woltz, C., Peters, G. \& Gotz, F. (1997). A site-directed Staphylococcus aureus hemB mutant is a small colony variant which persists intracellularly. $J$ Bacteriol 179, 4706-4712.

Emori, T. G. \& Gaynes, R. P. (1993). An overview of nosocomial infections, including the role of the microbiology laboratory. Clin Microbiol Rev 6, 428-442.

Foster, T. J. \& McDevitt, D. (1994). Surface-associated proteins of Staphylococcus aureus: their possible roles in virulence. FEMS Microbiol Lett 118, 199-206.

Greene, C. (1995). Studies on fibronectin binding proteins of Staphylococcus aureus. PhD thesis, Trinity College, Dublin.

Greene, C., McDevitt, D., François, P., Vaudaux, P. E., Lew, D. P. \& Foster, T. J. (1995). Adhesion properties of mutants of Staphylococcus aureus defective in fibronectin-binding proteins and studies on the expression of $f n b$ genes. Mol Microbiol 17, $1143-1152$.

Hartford, O., François, P., Vaudaux, P. \& Foster, T. J. (1997). The dipeptide repeat region of the fibrinogen-binding protein (clumping factor) is required for functional expression of the fibrinogen-binding domain on the Staphylococcus aureus cell surface. Mol Microbiol 25, 1065-1076.

Hienz, S. A., Schennings, T., Heimdahl, A. \& Flock, J.-I. (1996). Collagen binding of Staphylococcus aureus is a virulence factor in experimental endocarditis. J Infect Dis 174, 83-88.

Hiramatsu, K., Hanaki, H., Ino, T., Yabuta, K., Oguri, T. \& Tenover, T. C. (1997a). Methicillin-resistant Staphylococcus aureus clinical strain with reduced vancomycin susceptibility. J Antimicrob Chemother 40, 135-136.

Hiramatsu, K., Aritaka, N., Hanaki, H., Kawasaki, S., Hosoda, Y., Hori, S., Fukuchi, Y. \& Kobayashi, I. (1997b). Dissemination in Japanese hospitals of strains of Staphylococcus aureus heterogeneously resistant to vancomycin. Lancet 350, 1670-1673.

Huff, S., Matsuka, Y. V., McGavin, M. J. \& Ingham, K. C. (1994). Interaction of $\mathrm{N}$-terminal fragments of fibronectin with synthetic and recombinant D-motifs from its binding protein on Staphylococcus aureus studied using fluorescence anisotropy. $J$ Biol Chem 269, 15563-15570.

Ing, M. B., Baddour, L. M. \& Bayer, S. A. (1997). Bacteremia and infective endocarditis: pathogenesis, diagnosis, and complications. In The Staphylococci in Human Disease, 1st edn, pp. 331-354. Edited by K. B. Crossley \& G. L. Archer. New York: Churchill Livingstone.

Jaffe, E. A. \& Mosher, D. F. (1978). Synthesis of fibronectin by cultured human endothelial cells. J Exp Med 147, 1779-1791.

Jaffe, E. A., Nachman, R. L., Backer, C. G. \& Minick, C. R. (1973a). Culture of human endothelial cells derived from umbilical veins. Identification by morphologic and immunologic criteria. J Clin Invest 52, 2745-2756.

Jaffe, E. A., Hoyer, L. N. \& Nachman, R. L. (1973b). Synthesis of antihemophilic factor antigen by cultured human endothelial cells. J Clin Invest 52, 2757-2764.

Joh, H. J., House-Pompeo, K., Patti, J. M., Gurusiddappa, S. \&
Höök, M. (1994). Fibronectin receptors from Gram-positive bacteria : comparison of active sites. Biochemistry 33, 6086-6092.

Johnson, C. M. (1993). Staphylococcus aureus binding to cardiac endothelial cells is partly mediated by a 130 kilodalton glycoprotein. J Lab Clin Med 121, 675-682.

Jonsson, K., Signas, C., Muller, H.-P. \& Lindberg, M. (1991). Two different genes encode fibronectin binding proteins in Staphylococcus aureus. The complete nucleotide sequence and characterization of the second gene. Eur J Biochem 202, 1041-1048.

Karakawa, W. W. \& Vann, W. F. (1982). Capsular polysaccharides of Staphylococcus aureus. Semin Infect Dis 4, 285-293.

Lowy, F. D., Fant, J., Higgins, L. L., Ogawa, S. K. \& Hatcher, V. B. (1988). Staphylococcus aureus-human endothelial cell interactions. J Ultrastruct Mol Struct Res 98, 137-146.

McCormick, C. J., Craig, A., Roberts, D., Newbold, C. I. \& Berendt, A. R. (1997). Intercellular adhesion molecule-1 and CD36 synergize to mediate adherence of Plasmodium falciparuminfected erythrocytes to cultured human microvascular endothelial cells. J Clin Invest 100, 2521-2529.

McDevitt, D., Vaudaux, P. \& Foster, T. J. (1992). Genetic evidence that bound coagulase of Staphylococcus aureus is not clumping factor. Infect Immun 60, 1514-1523.

McDevitt, D., François, P., Vaudaux, P. \& Foster, T. J. (1994). Molecular characterization of the clumping factor (fibrinogen receptor) of Staphylococcus aureus. Mol Microbiol 11, 237-248.

Menzies, B. E. \& Kourteva, I. (1998). Internalization of Staphylococcus aureus by endothelial cells induces apoptosis. Infect Immun 66, 5994-5998.

Moreillon, P., Entenza, J. M., Francioli, P., McDevitt, D., Foster, T. J., François, P. \& Vaudaux, P. (1995). Role of Staphylococcus aureus coagulase and clumping factor in pathogenesis of experimental endocarditis. Infect Immun 63, 4738-4743.

Novick, R. P. (1967). Properties of a cryptic high frequency transducing phage in Staphylococcus aureus. Virology 33, 156-166.

O'Connell, D. P., Nanavaty, T., McDevitt, D., Gurusiddappa, S., Höök, M. \& Foster, T. J. (1998). The fibrinogen-binding MSCRAMM (clumping factor) of Staphylococcus aureus has a $\mathrm{Ca}^{2+}$-dependent inhibitory site. J Biol Chem 273, 6821-6829.

Ogawa, S. K., Yurberg, E. R., Hatcher, V. B., Levitt, M. A. \& Lowy, F. D. (1985). Bacterial adherence to human endothelial cells in vitro. Infect Immun 50, 218-224.

Ozeri, V., Rosenshine, I., Mosher, D. F., Fässler, R. \& Hanski, E. (1998). Roles of integrins and fibronectin in the entry of Streptococcus pyogenes into cells via protein F1. Mol Microbiol 30, 625-637.

Panlilio, A., Culver, D. H., Gaynes, P. R., Banerjee, S., Henderson, T. S., Tolson, J. S. \& Martone, W. J. (1992). Methicillin-resistant Staphylococcus aureus in U.S. hospitals, 1975-1991. Infect Control Hosp Epidemiol 13 , 582-586.

Patel, A. H., Nowlan, P., Weavers, E. D. \& Foster, T. J. (1987). Virulence of protein A-deficient and alpha-toxin-deficient mutants of Staphylococcus aureus isolated by allele replacement. Infect Immun 55, 3103-3110.

Patti, J. M., Bremell, T., Krajewska-Pietrasik, D., Abdelnour, A., Tarkowski, A., Ryden, C. \& Höök, M. (1994a). The Staphylococcus aureus collagen adhesin is a virulence determinant in experimental septic arthritis. Infect Immun 62, 152-161.

Patti, J. M., Allen, B. L., McGavin, M. J. \& Höök, M. (1994b). MSCRAMM-mediated adherence of microorganisms to host tissues. Annu Rev Microbiol 48, 585-617. 
Phonimdaeng, P., O’Reilly, M., Nowlan, P., Bramley, A. J. \& Foster, T. J. (1990). The coagulase of Staphylococcus aureus 8325 4. Sequence analysis and virulence of site-specific coagulasedeficient mutants. Mol Microbiol 4, 393-404.

Proctor, R. A., Christman, G. \& Mosher, D. F. (1984). Fibronectininduced agglutination of Staphylococcus aureus correlates with invasiveness. J Lab Clin Med 104, 455-469.

Raja, R. H., Raucci, G. \& Höök, M. (1990). Peptide analogues to a fibronectin receptor inhibit attachment of Staphylococcus aureus to fibronectin-coated surfaces. Infect Immun 58, 2593-2598.

Sau, S., Bhasin, N., Wann, E. R., Lee, J. C., Foster, T. J. \& Lee, C. Y. (1997). The Staphylococcus aureus allelic genetic loci for serotype 5 and 8 capsule expression contain the type-specific genes flanked by common genes. Microbiology 143, 2395-2405.

Sherertz, R. J., Carruth, W. A., Hampton, A. A., Byron, M. P. \& Solomon, D. D. (1993). Efficacy of antibiotic-coated catheters in preventing subcutaneous Staphylococcus aureus infection in rabbits. J Infect Dis 167, 98-106.

Signas, C., Raucci, G., Jonsson, K., Lindgren, P.-E., Anantharamaiah, G. M., Höök, M. \& Lindberg, M. (1989). Nucleotide sequence of the gene for a fibronectin-binding protein from Staphylococcus aureus: use of this peptide sequence in the synthesis of biologically active peptides. Proc Natl Acad Sci USA 86, 699-703.

Soell, M., Diab, M., Haan-Archipoff, G., Beretz, A., Herbelin, C., Poutrel, B. \& Klein, J.-P. (1995). Capsular polysaccharide types 5 and 8 of Staphylococcus aureus bind specifically to human epithelial (KB) cells, endothelial cells, and monocytes and induce release of cytokines. Infect Immun 63, 1380-1386.

Sottile, J., Schwarzbauer, J., Selegue, J. \& Mosher, D. F. (1991). Five type I modules of fibronectin form a functional unit that binds to fibroblasts and Staphylococcus aureus. J Biol Chem 266, 12840-12843.

Speller, D. C. E., Johnson, A. P., James, D., Marples, R. R., Charlett, A. \& George, R. C. (1997). Resistance to methicillin and other antibiotics in isolates of Staphylococcus aureus from blood and cerebrospinal fluid, England and Wales, 1989-1995. Lancet 350, 232-235.

Steinberg, J. P., Clark, C. C. \& Hackman, B. O. (1996). Nosocomial and community-acquired Staphylococcus aureus bacteremias from 1980 to 1993 : impact of intravenous devices and methicillin resistance. Clin Infect Dis 23, 255-259.

Tompkins, D. C., Hatcher, V. B., Patel, D., Orr, G. A., Higgins, L. L. \& Lowy, F. D. (1990). A human endothelial cell membrane protein that binds Staphylococcus aureus in vitro. J Clin Invest 85, $1248-1254$.
Vann, J. M. \& Proctor, R. A. (1987). Ingestion of Staphylococcus aureus by bovine endothelial cells results in time- and inoculumdependent damage to endothelial cell monolayers. Infect Immun 55, 2155-2163.

Vann, J. M. \& Proctor, R. A. (1988). Cytotoxic effects of ingested Staphylococcus aureus on bovine endothelial cells: role of $S$. aureus alpha-hemolysin. Microb Pathog 4, 443-453.

Vann, J. M., Hamill, R. J., Albrecht, R. M., Mosher, D. F. \& Proctor, R. A. (1989). Immunoelectron microscopic localization of fibronectin in adherence of Staphylococcus aureus to cultured bovine endothelial cells. J Infect Dis 160, 538-542.

Vaudaux, P., Pittet, D., Haeberli, A., Huggler, E., Nydegger, U. E., Lew, D. P. \& Waldvogel, F. A. (1989). Host factors selectively increase staphylococcal adherence on inserted catheters: a role for fibronectin and fibrinogen or fibrin. J Infect Dis 160, 865-875.

Vaudaux, P., Pittet, D., Haeberli, A., Lerch, P. G., Morgenthaler, J. J., Proctor, R. A., Waldvogel, F. A. \& Lew, D. P. (1993). Fibronectin is more active that fibrin or fibrinogen in promoting Staphylococcus aureus adherence to inserted intravascular devices. J Infect Dis 167, 633-641.

Vaudaux, P., François, P., Proctor, R. A., McDevitt, D., Foster, T. J., Albrecht, R. M., Lew, D. P., Wabers, H. \& Cooper, S. L. (1995). Use of adhesion-defective mutants of Staphylococcus aureus to define the role of specific plasma proteins in promoting bacterial adhesion to canine arteriovenous shunts. Infect Immun 63, 585-590.

Vercellotti, G. M., Lussenhop, D., Peterson, P. K., Furcht, L. T., McCarthy, J. B., Jacob, H. S. \& Moldow, C. F. (1984). Bacterial adherence for fibronectin and endothelial cells: a possible mechanism for bacterial tissue tropism. J Lab Clin Med 103, 34-43.

Waldvogel, F. A. (1995). Staphylococcus aureus (including toxic shock syndrome). In Mandell, Douglas and Bennett's Principles and Practice of Infectious Diseases, 4th edn, vol. 2, pp. 1754-1777. Edited by G. L. Mandell, J. E. Bennett \& R. Dolins. New York: Churchill Livingstone.

Yao, L., Bengualid, V., Lowy, F. D., Gibbons, J. J., Hatcher, V. B. \& Berman, J. W. (1995). Internalization of Staphylococcus aureus by endothelial cells induces cytokine gene expression. Infect Immun 63, 1835-1839.

Yao, L., Lowy, F. D. \& Berman, J. W. (1996). Interleukin-8 gene expression in Staphylococcus aureus-infected endothelial cells. Infect Immun 64, 3407-3409.

Received 18 May 1999; revised 27 July 1999; accepted 17 August 1999. 